\title{
Chieseiceras dolomiticum n. sp. (Ammonoidea) and its significance for the calibration of the Triassic platform interior stratigraphy at Latemar (Southern Alps, Italy)
}

\author{
Peter Brack ${ }^{1} \cdot$ Hans Rieber ${ }^{2}$ \\ Received: 29 November 2018 / Accepted: 31 January 2019/Published online: 13 February 2019 \\ (C) Akademie der Naturwissenschaften Schweiz (SCNAT) 2019
}

\begin{abstract}
The species Chieseiceras dolomiticum n. sp. along with other ammonoid species (Latemarites latemarensis, Halilucites rusticus) helps constraining the age of the cyclic platform interior portion at Latemar (Dolomites, northern Italy). The comparison of ammonoids from the Latemar platform with the fossil record in basinal successions in the Southern Alps (including the Ladinian GSSP section at Bagolino) and Hungary suggests that the entire rhythmically bedded Latemar interval is entirely late Anisian in age. More than 400 stratigraphical metres of bedded shallow water carbonates at Latemar are found to correspond to less than $5 \mathrm{~m}$ of siliceous nodular limestone in the pelagic succession at Bagolino. The refined correlation will be significant for the reassessment of the cyclic Latemar stratigraphy in the light of new geochronological calibration of the South Alpine Middle Triassic.
\end{abstract}

Keywords Middle Triassic $\cdot$ Dolomites $\cdot$ Latemar $\cdot$ Carbonate platforms $\cdot$ Ammonoids

\section{Introduction}

Middle Triassic carbonate platforms in the Southern Alps are unique for the rather unusual but relatively widespread occurrences of age diagnostic "pelagic" fossils (ammonoids and Daonella, thin-shelled pelecypods). These fossils provide the most important ties for a detailed correlation of platform carbonates with coeval basinal sedimentary rocks (Brack and Rieber 1993; Fantini Sestini 1994, 1996; De Zanche et al. 1995; Manfrin et al. 2005).

Among the South Alpine platforms (Fig. 1), Latemar is exceptional because numerous fossil-bearing horizons occur in a pile of spectacularly exposed, regularly bedded and shallow dipping platform interior strata. The setting represents a temporal succession and helps in calibration

Editorial Handling: C. Klug.

Peter Brack

peter.brack@erdw.ethz.ch

1 Departement Erdwissenschaften, ETH Zürich, Sonneggstrasse 5, 8092 Zurich, Switzerland

2 Paläontologisches Institut und Museum, Universität Zürich, Zurich, Switzerland because it offers the rare opportunity to assess the factors controlling the cyclic bedding in shallow water carbonates.

In the past three decades, the sedimentology at Latemar has been studied in detail (Goldhammer et al. 1987, 1990; Egenhoff et al. 1999; Preto et al. 2004; Zühlke 2004; Emmerich et al. 2005; Marangon et al. 2011). However, divergent opinions on bedding characteristics and their durations triggered a heated debate, in the literature sometimes referred to as the "Latemar controversy" (Hinnov and Goldhammer 1991; Brack et al. 1996; Preto et al. 2001; Mundil et al. 2003; Zühlke et al. 2003; Kent et al. 2004; Meyers 2008). The discussion centres around the interpretation of (sub) metre-scale Latemar cycles driven by sea-level oscillations at Milankovitch or sub-Milankovitch frequencies.

In basinal successions, the ammonoid record coeval with the Latemar interval is well known from the Buchenstein Formation and other formations across the Southern Alps (e.g., Brack and Rieber 1993; Mietto et al. 2003; Preto et al. 2005) as well as from similar lithological units in the Balaton Highland in Hungary (Vörös 1998; Pálfy et al. 2003). Much of the palaeontological information is known from the GSSP section of the Ladinian Stage at Bagolino (Brack et al. 2005). Stratigraphic data from well-studied coeval Hungarian sections can be projected in detail onto Bagolino (Vörös et al. 


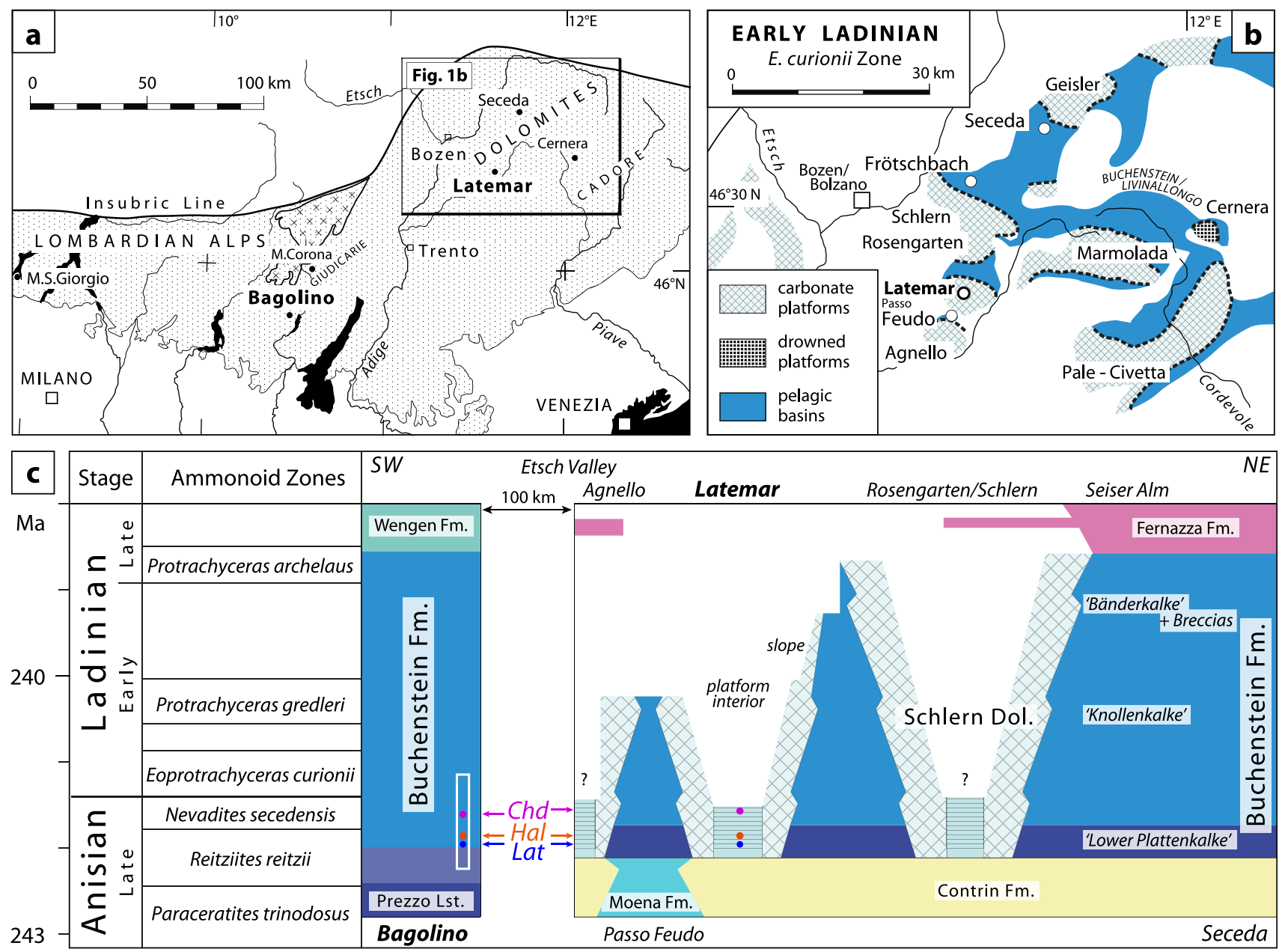

Fig. 1 a Overview of the central and western Southern Alps showing the location of the Bagolino reference section in eastern Lombardy as well as the map of $\mathbf{b}$. b Distribution of carbonate platforms and basins in the central and western Dolomites during the late Anisian-early Ladinian. c Chronostratigraphic scheme for upper Anisian to Ladinian formations in eastern Lombardy (Bagolino) and in the northwestern

2008). This correlation adds further biostratigraphic constraints on the duration of the Latemar cycles.

In a first step towards the reevaluation of the bedding systematics at Latemar in the light of an improved recent geochronology-based age calibration of the South Alpine Middle Triassic (Wotzlaw et al. 2018; Storck et al. 2019), this article briefly summarises the most important biostratigraphic age information for the platform interior succession at Latemar. This is complemented by new data including an ammonoid species (Chieseiceras dolomiticum n. sp.) that helps constraining the temporal allocation of the platform interior succession at Latemar. The material, upon which the new species is based, was discovered two decades ago by students of the University of Heidelberg, on the summit of Cimon del Latemar (Dolomites, northern Italy). A rock slab packed with small fossils (predominantly ammonoids) and with the size of about two bricks was donated by Rainer
Dolomites (modified after Storck et al. 2019). The white bar in the Bagolino column marks the stratigraphic interval shown in Fig. 2. The stratigraphic positions of key ammonoids at Latemar and in the basinal successions are indicated (Lat: Latemarites latemarensis, Hal: Halilucites rusticus, Chd: Chieseiceras dolomiticum)

Zühlke (then at the University of Heidelberg) to Hans Rieber (Palaeontological Institute of the University of Zürich) for preparation and study. A joint visit of the locality allowed us to verify the bedrock origin of this material.

\section{The Latemar platform}

Latemar was a possibly isolated carbonate platform with a diameter of around $3 \mathrm{~km}$. The current exposures display a bedded core from which slope deposits dip radially away with up to $35^{\circ}$ steep clinoforms. At the toe of the slopes, turbidites and breccias interfinger with basinal carbonates of the Buchenstein Formation. At Latemar, only parts of this facies change are preserved. The complete platformbasin transition is exposed in the neighbouring Rosengarten platform (e.g., Maurer 2000). 
The initial shape of the Latemar platform may have resembled a horseshoe with an embayment towards the deeply incised Val Sorda on the southeastern side of Latemar (Preto et al. 2011; Gramigna et al. 2013). Along the steep flanks of this valley, the platform interior succession is fully exposed and accessible. The bedded platform interior exceeds $600 \mathrm{~m}$ in thickness and has been divided into six lithozones (Egenhoff et al. 1999). The coarsely stratified Lower Platform Facies (LPF) and early slope clinoforms follow on top of the (pre-Latemar) Contrin Formation and are overlain by $\mathrm{dm}$ - to m-scale bedded intervals that are distinguished on the basis of relative abundance of exposure surfaces and tepee structures. In ascending order these include the Lower Tepee Facies (LTF), Lower Cyclic Facies (LCF), Middle Tepee Facies (MTF), Upper Cyclic Facies (UCF) and Upper Tepee Facies (UTF). The succession from LCF to UTF is over $450 \mathrm{~m}$ thick and hosts the disputed cyclic bedding patterns.

\section{Ammonoids at Latemar}

\section{Platform interior beds}

Ammonoids from Latemar have long been known (e.g., Richthofen 1860; Mojsisovics 1882; Philipp 1904; Wilckens 1909, Koken 1911; Bubnoff 1921; Assereto 1969; Gaetani et al. 1981) but most of these findings were from allochthonous blocks or from platform slope portions with unclear stratigraphy. However, in the past 30 years, ammonoids have been discovered also in numerous places located in the stratigraphic succession of the platform interior beds (Brack and Rieber 1993; De Zanche et al. 1995; Mietto and Manfrin 1995; Mundil et al. 2003; Zühlke 2004, Preto et al. 2004; Manfrin et al. 2005, see Fig. 3 in their article for locations). The fossil localities in the shallow water carbonates are in most cases less than one kilometre away from coeval platform margins. The shells of "pelagic" organisms were likely imported from the open sea and concentrated by (possibly storm-induced) currents. In the regularly stratified cyclic facies ammonoids and other fossils locally form coquinas in tepee cavities and in intertepee depressions (Egenhoff et al. 1999; Manfrin et al. 2005). The stratigraphically oldest level ("Lastei di Valsorda" in Brack and Rieber 1993) is a peculiar accumulation lagerstätte which Preto et al. (2011) consider to be part of the clinostratified infilling of a closed or semiclosed fault-bounded depression (their "tectonic blue hole") at the level of the LPF/LTF.

To date, ammonoids from over ten stratigraphically distinct levels constrain the biostratigraphic age of the cyclically bedded platform interior at Latemar to a short time span in the late Anisian. This corresponds to the upper $R$. reitzi to $N$. secedensis ammonoid zones of Brack et al.
(2005) and to the Avisianum to Secedensis (= Serpianensis) subzones of Manfrin et al. (2005).

Ammonoids from the oldest level including Latemarites latemarensis (= L. bavaricus of Manfrin et al. 2005), Aplococeras avisianum, Parakellnerites rothpletzi, Hungarites zalaensis and other taxa have been listed and illustrated in Brack and Rieber (1993). For comparable fossils and those from younger levels we refer to Manfrin et al. (2005, their localities TP 9-La 109; see also Preto et al. 2004 for the distribution of fossil layers). Our collection confirms the findings of these authors. Own finds include the following taxa:

- Parakellnerites rothpletzi and other forms of Parakellnerites, Aplococeras misanii, Hungarites, Tropigastrites, Gymnites from the Torre di Pisa (TP 9) locality;

- Parakellnerites waageni, Parakellnerites sp., Aplococeras misanii, ? Stoppaniceras from Cima di Valsorda (LCV 7-12, L 1, L 2);

- Aplococeras misanii, Celtitidae from a level corresponding to or somewhat above La 105.

Chieseiceras dolomiticum n. sp. described below is from the stratigraphically highest level of platform interior strata at Cimon del Latemar (ca. $1 \mathrm{~m}$ below its top layer). There, it occurs in association with numerous other ammonoids (Praepinacoceras airaghii, Norites cf. dieneri, Aplococeras misanii, Parakellnerites sp., Megaphyllites sp., Epigymnites sp., Sturia cf. forojulensi, Celtitidae) along with other cephalopods (Michelinoceras, Mojsisovicstheutis, ? Syringonautilus), gastropods and dasycladalean algae, in a laterally restricted accumulation of fossils.

From the stratigraphically largely equivalent level La 0 at Cimon del Latemar (i.e., $10 \mathrm{~m}$ below the top) Manfrin et al. (2005) also mention Proarcestes, Paranevadites and "Detoniceras". It is important to note that both faunas from Cimon del Latemar lack truly Ladinian elements such as Eoprotrachyceras, Protrachyceras and Arpadites. A fauna similar to Cimon del Latemar is known also from fossil lenses in the Esino Limestone of Val Parina in the Bergamask Alps (Fantini Sestini 1996). Ammonoids from outcrop S1060B in Val Parina comprise Praepinacoceras airaghii along with specimens of Parakellnerites, Norites, Aplococeras, Megaphyllites, Epigymnites and other taxa. This and other nearby lenses in Val Parina are older than those with faunas from the E. curionii Zone.

\section{Platform slope portions}

At Latemar ammonoids along with different forms of Daonella also occur in numerous places in platform slope deposits. However, due to the irregular platform geometry and complex architecture of the slope portions (Emmerich et al. 2005; Preto et al. 2011) fossils from these places can 
be used only as secondary constraints for the age of the platform interior succession. Some of the faunas occur in sedimentary dykes and as fills of cavities (Brack and Rieber 1993; Emmerich et al. 2005; Marangon et al. 2011).

The most prolific fossil-bearing slope spot hitherto known is at Isugadoi (Koken 1911; Brack and Rieber 1993). Daonella and ammonoids including representatives of Nevadites, Falsanolcites, Aplococeras misanii are indicative for the N. secedensis Zone (Brack et al. 2005). Similar Daonella were found also west of Gamsstallscharte.

Ammonoids from Schenon (Latemar Ostgipfel) including Arpadites (Philipp 1904; Wilckens 1909) and Protrachyceras cf. longobardicum $(=P$. ex gr. ladinum of Gaetani et al. 1981) are younger ("P. gredleri"Zone and younger levels) and might have been part of fissure fills (Gaetani et al. 1981). The same holds true for Daonella taramellii found in a sedimentary dyke crossing the slope deposits on the crest ca $140 \mathrm{~m}$ east-northeast of the highest point of Schenon (= fauna L4 in Brack et al. 1996).

\section{Correlation of basinal records with the platform interior at Latemar}

While many ammonoids reported from Latemar are long ranging forms or have insufficient diagnostic features allowing precise correlations, a few distinct Latemar ammonoid species occur within more restricted intervals in the basinal sediments (Fig. 2). Among these are representatives of Latemarites and Halilucites along with the new species of Chieseiceras described below. Latemarites latemarensis and Chieseiceras dolomiticum n. sp. occur in the lowest (at the level of Lower Tepee Facies, LTF, or somewhat below) and in the uppermost fossiliferous levels (Upper Tepee Facies, UTF), respectively, and are thus most important for constraining the base and the top of the cyclic platform interior portion at Latemar. From an intermediate position in this succession (Middle Tepee Facies, MTF; Cima di Valsorda-level LCV 12) Halilucites rusticus has been illustrated by Manfrin et al. (2005).

In basinal successions of the Southern Alps, Latemarites sp. has been mentioned from two sections in the eastern Dolomites (Preto et al. 2005). The basinal intervals there are more expanded and can be correlated only approximately with the reference sections of the Buchenstein Formation at Seceda or Bagolino. However, the species Latemarites latemarensis itself is well known from Hungarian localities (Vörös 1998; Pálfy et al. 2003). At Felsőörs it occurs between the horizons with Reitziites and Ticinites (Vörös et al. 2008), in an interval that is strongly expanded through interbedded, up to metre-thick volcanoclastic layers (Fig. 2). The Reitziites and Ticinites levels are known also from the GSSP section at Bagolino. There, only $\mathrm{mm}$ to $\mathrm{cm}$-thin volcaniclastic layers are found in the interval between Reitziites and Ticinites but the amount of carbonate layers compares well with the cumulative thickness of limestone beds and nodules at Felsöörs (see also Brack et al. 2005). Halilucites rusticus is known from Felsőörs in a stratigraphical position below the Ticiniteslayer as at Bagolino (Fig. 3; Mietto et al. 2003; Brack et al. 2005). A well-preserved specimen of Chieseiceras dolomiticum n. sp. (Fig. 3) is from a bed immediately above the Tc-tuff layers at Bagolino and was hitherto referred to with open nomenclature (Chieseiceras sp.; Brack et al. 2005). This level is within the $N$. secedensis ammonoid Zone.

The sequence of the three marker species from Latemar thus correlates with the combined Bagolino-Felsöörs record and the proportional vertical distance between the levels of these ammonoids is comparable. Moreover, this finding is in agreement with the distribution of other ammonoid taxa as far as their ranges can be judged.

In the Buchenstein Formation of the Southern Alps ornamented ammonoids (trachyostraca) are often known to occur at single levels or in rather restricted intervals. Around the Anisian-Ladinian boundary, a possibly typical range for the appearance of a single species may be seen in the distribution of the most abundant taxon Chieseiceras chiesense. In the nodular limestone facies of the Buchenstein Fm. of eastern Lombardy and Giudicarie (including Bagolino), the vertical distribution of this species known from numerous sections does not exceed $50 \mathrm{~cm}$ (Brack and Rieber 1986, 1993).

Even when doubling this value for the ranges of marker ammonoid taxa used here for correlation relative to the Bagolino setting, the proposed platform-basin comparison implies a correspondence of the $>400 \mathrm{~m}$ thick cyclic platform interior succession at Latemar with less than five stratigraphic metres of the Bagolino column (Fig. 3). The time interval for the cyclic facies at Latemar may thus be substantially shorter than hitherto assumed. This is shorter than the recent correlation proposed by Spahn et al. (2013) and adopted also by Franceschi et al. (2016). The correlation of Spahn et al. (2013) is based on the identification of magnetic reversals combined with the tracing of volcaniclastic layers. However, at least nine ash layers have been identified to date in the platform interior succession at Latemar (Zühlke 2004; Preto et al. 2005) and the correlation to the numerous volcaniclastic layers in the basinal successions is not straightforward. Moreover, the existence of a reversed polarity interval at Latemar as supposed by Spahn et al. (2013) is questionable (Kent et al. 2004).

\section{Conclusions}

The reevaluation of ammonoid data from Latemar and coeval basinal sections in the Southern Alps and Hungary confirms the short duration of the cyclic platform interior 


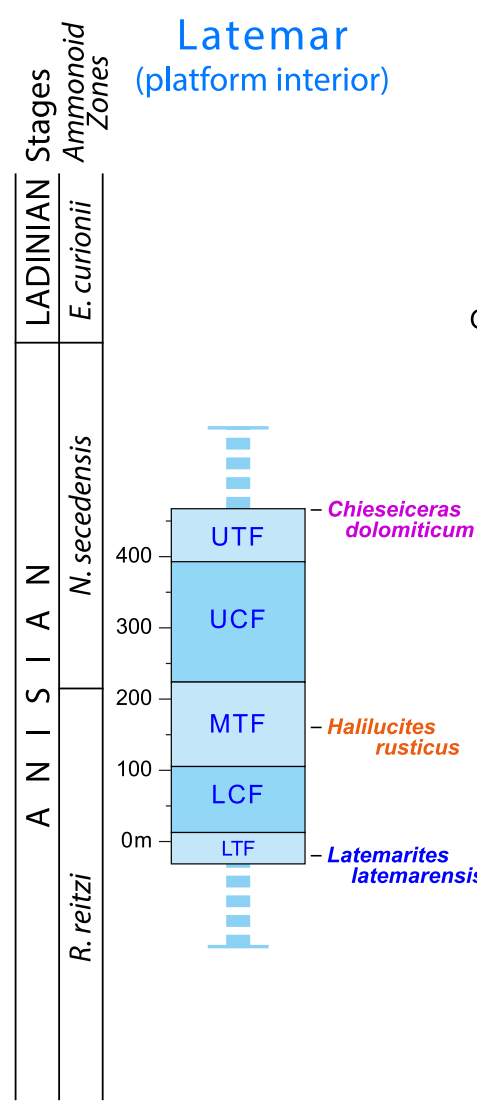

Bagolino (Southern Alps)

Felsőörs (Hungary)
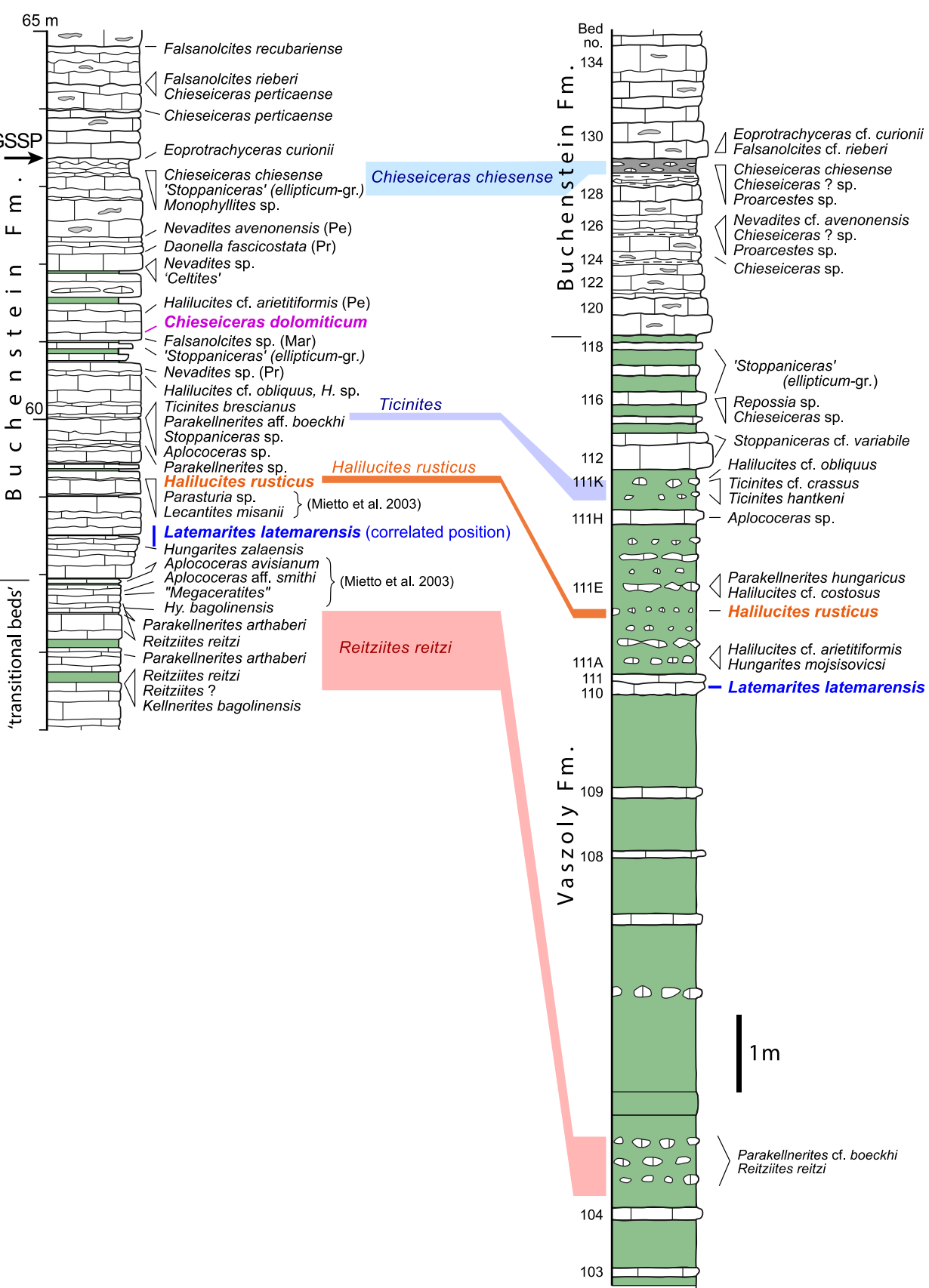

Fig. 2 Correlation of the platform interior succession at Latemar ( $L T F$ Lower Tepee Facies, LCF Lower Cyclic Facies, MTF Middle Tepee Facies, UCF upper Cyclic Facies, UTF Upper Tepee Facies; metre scale as for section "Latemartürme "in Zühlke et al. 2003) and basinal sections at Bagolino and Felsőörs (Hungary). Bagolino is updated and modified after Brack et al. (2005). A few important ammonoids and Daonella projected from nearby sections are labelled

interval at Latemar. The new ammonoid species Chieseiceras dolomiticum $\mathrm{n}$. sp. adds to the reliability of this correlation and reduces the range of uncertainty
(Pe: Pèrtica, Pr: Prezzo, Mar: Marcheno). Felsőörs is redrawn after Vörös et al. (2008, Figs. 3, 4). See their article for details of the correlation also of deeper parts of the sections below the Reitziites reitzi level. Green colour highlights volcaniclastic layers. The supposed maximal range of the Latemar succession relative to the Bagolino reference section is indicated (stippled blue line) (colour figure online)

especially for the top of the Latemar succession as preserved today. 


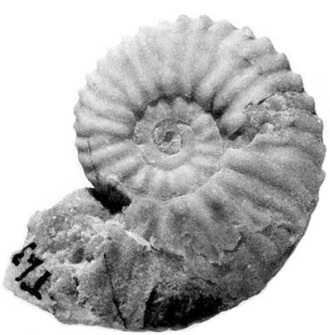

$1 a$

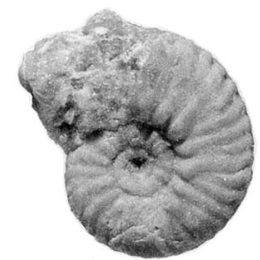

$4 a$

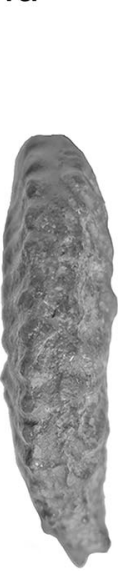

$7 b$

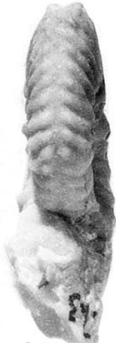

$1 \mathrm{~b}$

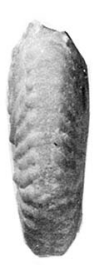

$4 b$

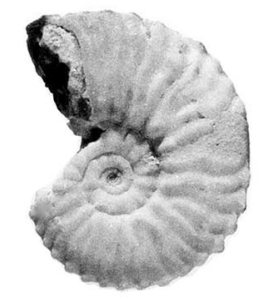

$2 a$

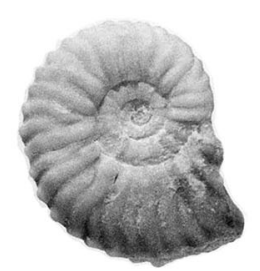

$5 a$

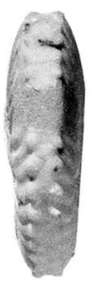

$2 b$

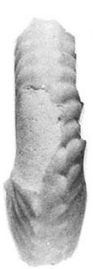

$5 b$

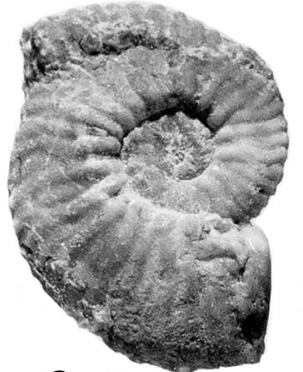

$3 a$

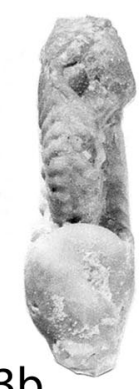

$3 b$

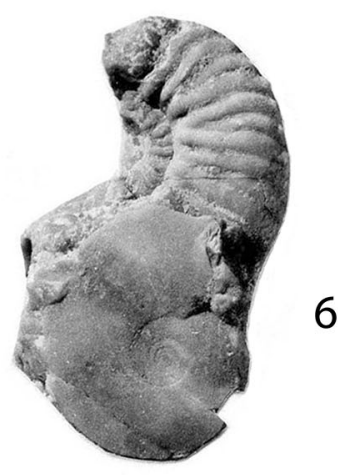

6

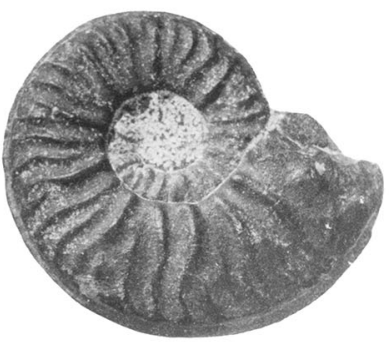

$8 a$

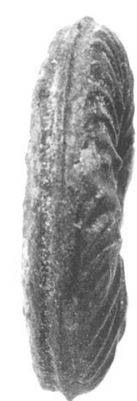

$8 b$
Fig. 3 Ammonoids from the peak of Cimon del Latemar and from the Buchenstein Fm. at Bagolino. 1-6:Chieseiceras dolomiticum n. sp., uppermost Latemar Lst. (top of Upper Tepee Facies) at Cimon del Latemar, 1: PIMUZ 25701 (holotype); 2: PIMUZ 36535; 3: PIMUZ 36536; 4: PIMUZ 36537; 5: PIMUZ 36538; 6: Ch. dolomiticum with

The resulting correlation implies that the $>400 \mathrm{~m}$ thick cyclic platform interior interval at Latemar is Late Anisian in age and unlikely exceeds the top of this stage. This interval rather corresponds to less than five stratigraphic metres in the GSSP-reference section at Bagolino (Fig. 2). The proposed refined correlation indicates that the Latemar succession is shorter than hitherto assumed. This correspondence will be relevant for a future calibration and interpretation of the bedding patterns at Latemar in terms of absolute ages and time span.

\section{Systematic description}

Subclass Ammonoidea Zittel, 1884
Praepinacoceras airaghii Fantini Sestini, 1996, PIMUZ 36539. 7: Chieseiceras dolomiticum n. sp., Buchenstein Fm., Bagolino (PIMUZ 36534). 8: Halilucites rusticus, Buchenstein Fm., Bagolino (PIMUZ 36533). The specimen collected in 2001 corresponds to the in situ imprint illustrated in Mietto et al. (2003, pl. 1, Fig. 17)

Order Ceratitida Hyatt, 1884

Superfamily Ceratitoidea Mojsisovics, 1879

Family Ceratitidae Mojsisovics, 1879

Subfamily Nevaditinae Tozer, 1994

Genus Chieseiceras Brack and Rieber, 1986

Chieseiceras dolomiticum n. sp.

Figure 3, 1-6.

Synonymy

? 1998 Chieseiceras chiesense (Mojsisovics)—Vörös, A. tab. 8, Fig. $4 \mathrm{a}+\mathrm{b}$

v 2003 Chieseiceras sp.-Bechstädt et al. (2003), FieldTrip to Latemar, fig III-15/1. 
Table 1 Morphological features of specimens of different species of Chieseiceras. Multipliers indicate observations on quarter whorls

\begin{tabular}{|c|c|c|c|c|c|}
\hline Specimen & $\begin{array}{l}\text { (A) } \\
\text { Diameter }(\mathrm{cm}) \text { at location } \\
\text { of measurements }\end{array}$ & $\begin{array}{l}\text { (B) } \\
\text { Umbilical width (\%) }\end{array}$ & $\begin{array}{l}\text { (C) } \\
\text { Umbilical nodes per } \\
\text { half whorl }\end{array}$ & $\begin{array}{l}\text { (D) } \\
\text { Marginal nodes per } \\
\text { half whorl }\end{array}$ & $\begin{array}{l}\text { Ratio } \\
(\mathrm{d} / \mathrm{c})\end{array}$ \\
\hline $\begin{array}{l}\text { Ch. dolomiticum } \\
\text { (PIMUZ 25701, Fig. 3/1) } \\
\text { holotype, Latemar }\end{array}$ & 2.6 & 38 & 9 & 18 & 2.0 \\
\hline $\begin{array}{l}\text { Ch. dolomiticum } \\
\text { (PIMUZ 36535, Fig. 3/2) } \\
\text { Latemar }\end{array}$ & 2.9 & 33 & 8.5 & 20 & 2.4 \\
\hline $\begin{array}{l}\text { Ch. dolomiticum } \\
\text { (PIMUZ 36537, Fig. 3/4) } \\
\text { Latemar }\end{array}$ & 2.35 & 32 & 9 & 20.5 & 2.3 \\
\hline $\begin{array}{l}\text { Ch. dolomiticum } \\
\text { (PIMUZ 36538, Fig. 3/5) } \\
\text { Latemar }\end{array}$ & 2.3 & 35 & 8 & 17.5 & 2.2 \\
\hline $\begin{array}{l}\text { Ch. dolomiticum } \\
\text { (PIMUZ 36534, Fig. 3/7) } \\
\text { Bagolino }\end{array}$ & 4.4 & 36 & $10^{-}$ & 21 & 2.1 \\
\hline $\begin{array}{l}\text { Ch. chiesense } \\
\text { (B\&R 1986, pl.1/Fig. 7) }\end{array}$ & 4.3 & 32.5 & $\begin{array}{l}2 \times 6 \\
12\end{array}$ & $\begin{array}{l}2 \times 15 \\
30\end{array}$ & 2.5 \\
\hline Bagolino & & & & & \\
\hline $\begin{array}{l}\text { Ch. chiesense } \\
\text { (B\&R 1986, pl.1/Fig. 1) } \\
\text { Bagolino }\end{array}$ & $\sim 3.5$ & 31.5 & $\begin{array}{l}2 \times 4.5 \\
9\end{array}$ & $\begin{array}{l}2 \times 11 \\
22\end{array}$ & 2.4 \\
\hline $\begin{array}{l}\text { Ch. perticaense } \\
\text { holotype Pèrtica Bassa } \\
\text { (B\&R 1986, pl.3/Fig. 1+4) }\end{array}$ & $\sim 5.0$ & - & 15 & 31 & 2.1 \\
\hline $\begin{array}{l}\text { Ch. perticaense } \\
\text { (B\&R 1986, pl.3/Fig. 3) } \\
\text { Pèrtica Bassa }\end{array}$ & 2.9 & 31 & 11 & 25 & 2.3 \\
\hline $\begin{array}{l}\text { Ch. pemphix } \\
\text { (Mojsisovics 1982, pl.39/Fig. 9) } \\
\text { San Salvatore }\end{array}$ & 3.7 & 40 & 8 & 20 & 2.5 \\
\hline
\end{tabular}

v 2005 Chieseiceras sp.-Brack et al., Fig. 7 (Bagolino column)

Holotype Specimen PIMUZ 25701, (Fig. 3/1a, b; the ammonoid is figured also on Fig. 2 of Mundil et al. 2003, but there with a wrong PIMUZ number).

Name Referring to the locality of discovery in the Dolomites (northern Italy).

Type locality and horizon The slab from which the holotype and many other small ammonoids and a few additional fossils were isolated was situated stratigraphically about $1 \mathrm{~m}$ below the top of the succession a few metres southeast of the cross on the summit of Cimon del Latemar (WGS84 coord.: $\left.\quad 46^{\circ} 22^{\prime} 52.0^{\prime \prime} \mathrm{N}, \quad 11^{\circ} 34^{\prime} 30.2^{\prime \prime} \mathrm{E}\right)$. The laterally restricted accumulation of fossils was found in lightcoloured calcareous sediments of the highest part of the
Upper Tepee Facies (UTF) in the Latemar Limestone (Sciliar Fm. in Gramigna et al. 2013).

Material Six small specimens and several fragments isolated from a slab of Latemar Limestone (platform facies) from Cimon del Latemar and two specimens from the pelagic Buchenstein Formation at Bagolino (eastern Lombardy, northern Italy).

Specimens labelled with PIMUZ-numbers are stored in the collection of the Palaeontological Institute and Museum of the University of Zurich.

Diagnosis Evolute Cheiseiceras with tabulate whorl section and broad, rectiradiate ribs. The ribs start at the umbilical border with a more or less blunt node. In different positions of the inner half of the flank secondary ribs are intercalated. On the outer half of the flank all ribs have 
the same thickness and end with uniform marginal nodes. The venter bordered by the slightly surpassing marginal nodes is even and smooth.

Description The diameter of the holotype and all other specimens isolated from the Latemar slab do not exceed $40 \mathrm{~mm}$. The specimen from the Ladinian GSSP section at Bagolino (Fig. 3/7a,b, PIMUZ 36534) has a diameter of at least $70 \mathrm{~mm}$. In specimens of the new species with a diameter between 26 and $43 \mathrm{~mm}$ the umbilical width varies between 32 and $38 \%$. The number of primaries and respective secondaries per half whorl varies between 8 and 10 and 17.5 and 21, respectively (Table 1). The section of the ribs is semicircular and in the specimens from Latemar the furrows between the ribs are narrow. The ventral smooth interruption of the ribs is narrow in the holotype (Fig. 3/1b) or considerably broader as in specimen PIMUZ 36537 (Fig. 3/4b). The marginal nodes of both sides have generally a corresponding position (not so in specimen PIMUZ 36534 in Fig. 3/7 from Bagolino).

Because of complete recrystallization of the specimens no suture or septa are visible. For this reason it is not possible to decide whether the ammonoid from Latemar is adult or juvenile or if it represents the inner whorls of an adult bigger form.

Comparison In Chieseiceras (genus established by Brack and Rieber 1986) the size of a specimen is critical for the habit. Especially in Chieseiceras chiesense (Mojsisovics 1882) the development of the ribs varies considerably during ontogeny. Therefore, only specimens of about the same size should be compared. Chieseiceras dolomiticum is more evolute and has broader ribs than $C h$. chiesense and Ch. perticaense. Chieseiceras pemphix (Merian, 1854) is more evolute and has a broader smooth venter. However, this form could be judged only from the illustrations in Hauer (1855) and Mojsisovics (1882) because the type itself is no longer available.

Discussion As none of the available specimens or fragments of Ch. dolomiticum points towards a diameter exceeding $70 \mathrm{~mm}$ and because no suture is visible, the size of an adult specimen remains uncertain.

Occurrence From its stratigraphic position Ch. dolomiticum is considered a late Anisian form (N. secedensis Zone). The specimens from Bagolino were found at the $61.2 \mathrm{~m}$ level in a layer above the Tc-tuff interval, i.e., in the middle part of the $N$. secedensis Zone (Fig. 2). The position of the Latemar specimens is less clear but they could possibly be somewhat younger.

Remarks The ammonoid species Ammonites pemphix Merian, 1854 is here included into the genus Chieseiceras Brack and Rieber, 1986. Based on the stratigraphic succession we propose the following, for ammonoids common, evolutionary trend from more evolute to more involute forms of Chieseiceras: Chieseiceras pemphix $\rightarrow$ Ch. dolomiticum $\rightarrow$ Ch. chiesense $\rightarrow$ Ch. perticaense.

Acknowledgements This article is a late outcome of a fruitful collaboration between the authors and members of the geological Institute of the University of Heidelberg. In July 2000 Thilo Bechstädt and Rainer Zühlke guided us to the fossil locality on the very top of Cimon del Latemar. There the group was lucky not only to identify the site, but also to survive a heavy thunderstorm and lightning. The article benefitted from suggestions made by three anonymous reviewers.

\section{References}

Assereto, R. (1969). Sul significato stratigrafico della "Zona ad Avisianus" del Trias Medio delle Alpi. Bollettino della Società Geologica Italiana, 88, 123-145.

Bechstädt, T., Brack, P., Preto, N., Rieber, H., \& Zühlke, R. (2003). Field Trip to Latemar, September $14-16 / 17,2003$. Triassic geochronology and cyclostratigraphy - a field symposium, St. Christina/Val Gardena, Dolomites, Italy, September 11-13, 2003. IUGS-STS. Guidebook.

Brack, P., Mundil, R., Oberli, F., Meier, M., \& Rieber, H. (1996). Biostratigraphic and radiometric age data question the Milankovitch characteristics of the Latemar cycles (Southern Alps, Italy). Geology, 24, 371-375.

Brack, P., \& Rieber, H. (1986). Stratigraphy and ammonoids of the lower Buchenstein Beds of the Brescian Prealps and Giudicarie and their significance for the Anisian/Ladinian boundary. Eclogae geologicae Helveticae, 79(1), 181-225.

Brack, P., \& Rieber, H. (1993). Towards a better definition of the Anisian/Ladinian boundary: new biostratigraphic data and correlations of boundary sections from the Southern Alps. Eclogae geologicae Helveticae, 86(2), 415-527.

Brack, P., Rieber, H., Nicora, A., \& Mundil, R. (2005). The Global Boundary Stratotype Section and Point (GSSP) of the Ladinian Stage (Middle Triassic) at Bagolino (Southern Alps, Northern Italy) and its implications for the Triassic time scale. Episodes, 28(4), 233-244.

Bubnoff, S. (1921). Die ladinische Fauna von Forno (Mezzavalle) bei Predazzo. Verhandlungen des Naturhistorisch-medizinischen Vereins zu Heidelberg. Neue Folge, 14, 257-636.

De Zanche, V., Gianolla, P., Manfrin, S., Mietto, P., \& Roghi, G. (1995). A middle Triassic back-stepping carbonate platform in the Dolomites (Italy): Sequence stratigraphy and Biochronostratigraphy. Memorie di Scienze Geologiche, 47, 135-155.

Egenhoff, S. O., Peterhänsel, A., Bechstädt, T., Zühlke, R., \& Grötsch, J. (1999). Facies architecture of an isolated carbonate platform; tracing the cycles of the Latemar (Middle Triassic, northern Italy. Sedimentology, 46, 893-912.

Emmerich, A., Zamparelli, V., Bechstädt, T., \& Zühlke, R. (2005). The reefal margin and slope of a Middle Triassic carbonate platform: the Latemar (Dolomites, Italy). Facies, 50, 573-614.

Fantini Sestini, N. (1994). The Ladinian ammonoids from Calcare di Esino of Val Parina (Bergamasc Alps Italy). Pt 1. Rivista Italiana di Paleontologia e Stratigrafia, 100(2), 227-284.

Fantini Sestini, N. (1996). The Ladinian ammonoids from the Calcare di Esino of Val Parina (Bergamasc Alps Italy) Pt 2. Rivista Italiana di Paleontologia e Stratigrafia, 102(2), 211-226.

Franceschi, M., Preto, N., Marangon, A., Gattolin, G., \& Meda, M. (2016). High precipitation rate in a Middle Triassic carbonate 
platform: Implications on the relationship between seawater saturation state and carbonate production. Earth and Planetary Science Letters, 444, 215-224.

Gaetani, M., Fois, E., Jadoul, F., \& Nicora, A. (1981). Nature and evolution of Middle Triassic carbonate buildups in the Dolomites (Italy). Marine Geology, 44, 25-57.

Goldhammer, R. K., Dunn, P. A., \& Hardie, L. A. (1987). High frequency glacioeustatic sea level oscillations with Milankovitch characteristics recorded in Middle Triassic platform carbonates in northern Italy. American Journal of Science, 287, 853-892.

Goldhammer, R. K., Dunn, P. A., \& Hardie, L. A. (1990). Depositional cycles, composite sea-level changes, cycle stacking patterns, and the hierarchy of stratigraphic forcing: Examples from the Alpine Triassic platform carbonates. Geological Society of America Bulletin, 102, 535-562.

Gramigna, P., Franceschi, M., Gattolin, G., Preto, N., Massironi, M., Riva, A., et al. (2013). Geological map of the Middle Triassic Latemar platform (Western Dolomites, Northern Italy). Journal of Maps, 9, 313-324.

Hauer, F. (1855). Über einige Fossilien aus dem Dolomit des Monte Salvatoe bei Lugano. Sitzungsberichte der Kaiserlichen Akademie der Wissenschaften, mathematisch-naturwissenschaftliche Classe, 15, 407-417.

Hinnov, L. A., \& Goldhammer, R. K. (1991). Spectral analysis of the Middle Triassic Latemar Limestone. Journal of Sedimentary Petrology, 61, 1173-1193.

Kent, D. V., Muttoni, G., \& Brack, P. (2004). Magnetostratigraphic confirmation of a much faster tempo for sea-level change for the Middle Triassic Latemar platform carbonates. Earth and Planetary Science Letters, 228, 369-377.

Koken, E. (1911). Zur Geologie Südtirols. I. Die Wengener Kalke. Centralblatt für Mineralogie, Geologie und Paläontologie, 1911, 561-572.

Manfrin, S., Mietto, P., \& Preto, N. (2005). Ammonoid biostratigraphy of the Middle Triassic Latemar platform (Dolomites, Italy) and its correlation with Nevada and Canada. Geobios, 38, 477-504.

Marangon, A., Gattolin, G., Della Porta, G., \& Preto, N. (2011). The Latemar: a flat-topped, steep fronted platform dominated by microbialites and synsedimentary cements. Sedimentary Geology, 240, 97-114.

Maurer, F. (2000). Growth mode of Middle Triassic carbonate platforms in the Western Dolomites (Southern Alps, Italy). Sedimentary Geology, 134, 275-286.

Merian, P. (1854). Muschelkalk-Versteinerungen im Dolomite des Monte S. Salvatore bei Lugano. Verhandlungen der naturforschenden Gesellschaft Basel, 1, 84-90.

Meyers, S. R. (2008). Resolving Milankovitchian controversies: The Triassic Latemar Limestone and the Eocene Green River Formation. Geology, 36(4), 319-322.

Mietto, P., Gianolla, P., Manfrin, S., \& Preto, N. (2003). Refined ammonoid biochronostratigraphy of the Bagolino section (Lombardian Alps, Italy), GSSP candidate for the base of the Ladinian Stage. Rivista Italiana di Paleoontologia e Stratigrafia, 109(3), 449-462.

Mietto, P., \& Manfrin, S. (1995). A high resolution Middle Triassic ammonoid standard scale in the Tethys Realm. A preliminary report. Bulletin de la Société Géologique de France, 166, 539-563.

Mojsisovics, E.v. (1882). Die Cephalopoden der mediterranen Triasprovinz. Abhandlungen der k.k. geologischen Reichsanstalt, $10,322$.

Mundil, R., Zühlke, R., Bechstaedt, T., Peterhänsel, A., Egenhoff, S. O., Oberli, F., et al. (2003). Cyclicities in Triassic platform carbonates: synchronizing radio-isotopic and orbital clocks. Terra Nova, 15(2), 81-87.
Pálfy, J., Parrish, R. R., \& Vörös, A. (2003). Mid-Triassic integrated $\mathrm{U}-\mathrm{Pb}$ geochronology and ammonoid biochronology from the Balaton Highland (Hungary). Journal of the Geological Society, 160, 271-284.

Philipp, H. (1904). Paläontologisch-geologische Untersuchungen aus dem Gebiet von Predazzo. Zeitschrift der deutschen geologischen Gesellschaft, 56, 1-98.

Preto, N., Franceschi, M., Gattolin, G., Massironi, M., Riva, A., Gramigna, P., et al. (2011). The Latemar: a Middle Triassic polygonal fault-block platform controlled by synsedimentary tectonics. Sedimentary Geology, 234, 1-18.

Preto, N., Hinnov, L. A., De Zanche, V., Mietto, P., \& Hardie, L. A. (2004). The Milankovitch interpretation of the Latemar platform cycles (Dolomites, Italy): Implications for geochronology, biostratigraphy, and Middle Triassic carbonate accumulation. In D'Argenio et al. (Eds.), Cyclostratigraphy: Approaches and case histories: SEPM (Society for Sedimentary Geology) Special Publication (81, pp. 167-182)

Preto, N., Hinnov, L. A., Hardie, L. A., Blaustein, M. K., \& De Zanche, V. (2001). Middle Triassic orbital signature recorded in the shallow-marine Latemar carbonate buildup (Dolomites, Italy). Geology, 29, 1123-1126.

Preto, N., Spötl, C., Mietto, P., Gianolla, P., Riva, A., \& Manfrin, S. (2005). Aragonite dissolution, sedimentation rates and carbon isotopes in deep-water hemipelagites (Livinallongo Formation, Middle Triassic, northern Italy). Sedimentary Geology, 181, 173-194.

Richthofen, F.v. (1860). Geognostische Beschreibung der Umgegend von Predazzo, Sanct Cassian und der Seisser Alpe in Süd-Tyrol (p. 327). Gotha: Justus-Perthes.

Spahn, Z. P., Kodama, K. P., \& Preto, N. (2013). High-resolution estimate for the depositional duration of the Triassic Latemar platform: A new magnetostratigraphic and magnetic susceptibility cyclostratigraphy from basinal sediments at Rio Sacuz, Italy. Geochemistry, Geophysics, Geosystems, 14, 1245-1257.

Storck, J.-C., Brack, P., Wotzlaw, J.-F., \& Ulmer, P. (2019). Timing and evolution of Middle Triassic magmatism in the Southern Alps (Northern Italy). Journal of the Geological Society. https:// doi.org/10.1144/jgs2018-123.

Vörös, A. (1998). A Balaton-felvidék Triás ammonoideái és biostratigrádiája (Triassic ammonoids and biostratigraphy of the Balaton Highland). Magyar Természettudományi Múzeum, Studia Naturalia, 12, 1-105. [in Hungarian].

Vörös, A., Budai, T., \& Szabó, I. (2008). The base of the Curionii Zone (Ladinian, Triassic) in Felsõörs (Hungary): improved correlation with the Global Stratotype Section. Central European Geology, 51(4), 325-339.

Wilckens, R. (1909). Paläontologische Untersuchung triadischer Faunen aus der Umgebung von Predazzo in Südtirol. Verhandlungen des naturhistorischen-medizinischen Vereins zu Heidelberg. Neue Folge, 10, 81-231.

Wotzlaw, J.-F., Brack, P., \& Storck, J.-C. (2018). High-resolution stratigraphy and zircon $\mathrm{U}-\mathrm{Pb}$ geochronology of the Middle Triassic Buchenstein Formation (Dolomites, northern Italy): precession-forcing of hemipelagic carbonate sedimentation and calibration of the Anisian-Ladinian boundary interval. Journal of the Geological Society, 175, 71-85.

Zühlke, R. (2004). Integrated cyclostratigraphy of a model Mesozoic carbonate platform - the Latemar (Middle Triassic, Italy). In D'Argenio et al. (Eds.), Cyclostratigraphy: Approaches and case histories: SEPM (Society for Sedimentary Geology) Special Publication, (81, pp. 183-211)

Zühlke, R., Bechstädt, T., \& Mundil, R. (2003). Sub-Milankovitch and Milankovitch forcing on a model Mesozoic carbonate platform-the Latemar (Middle Triassic, Italy). Terra Nova, 15, 69-80. 